\title{
Hepatocellularcarcinoma: current imaging techniques
}

\author{
S De Luca*, E Casalini Vañek, A Vazquez, M Wirtz, F Troncoso, E Eyheremendy \\ From International Cancer Imaging Society Meeting and 15th Annual Teaching Course (ICIS 2015) \\ London, UK. 5-7 October 2015
}

\section{Learning objectives}

Describe the use of current imaging techniques to reach a correct diagnosis of hepatocellular carcinoma.

Emphasise the knowledge of complementary tools for the evaluation of early response to treatment tumour.

\section{Content organisation}

Our cases will be presented in a pictorial essay mode.

It is important to consider:

The radiologic diagnosis of $\mathrm{HCC}$ can be made by either CT or MRI methods.

Typically, HCC enhances during the arterial phase due to the presence of an intense arterial blood supply of the hepatic arteries.

TC dual Energy: Dual-energy CT (DECT) is an innovative imaging technique that operates on the basic principle of application of two distinct energy settings that make the transition from $\mathrm{CT}$ attenuation-based imaging to material-specific or spectral imaging. DECT can also aid in evaluation of response to therapy and detection of oncology-related disorders.

MDCT perfusion: non-invasive method of quantification of tumour blood supply, related to the formation of new arterial structures (neoangiogenesis), which are essential for tumour growth.

\section{Conclusion}

Dual energy and perfusion CT are innovative techniques to detect suspicious lesions of hepatocarcinoma.

Dual Energy CT also helps to reduce radiation exposure by using low dose imaging protocols without affecting diagnostic purpose.

The Perfusion provides information on the neovascularization of an injury (predicting malignancy) and

\footnotetext{
* Correspondence: sdeluca@hospitalaleman.com Hospital Aleman, Buenos Aires, Argentina
}

C 2015 De Luca et al. This is an Open Access article distributed under the terms of the Creative Commons Attribution License (http:// creativecommons.org/licenses/by/4.0), which permits unrestricted use, distribution, and reproduction in any medium, provided the original work is properly cited. The Creative Commons Public Domain Dedication waiver (http://creativecommons.org/publicdomain/ zero/1.0/) applies to the data made available in this article, unless otherwise stated.

Submit your next manuscript to BioMed Central and take full advantage of:

- Convenient online submission

- Thorough peer review

- No space constraints or color figure charges

- Immediate publication on acceptance

- Inclusion in PubMed, CAS, Scopus and Google Scholar

- Research which is freely available for redistribution 